Pacific Journal of Mathematics

ON THE KONHAUSER SETS OF BIORTHOGONA
POLYNOMIALS SUGGESTED BY THE LAGER

H. M. (HARL MOAN) SRIVASTAVA 


\title{
ON THE KONHAUSER SETS OF BIORTHOGONAL POLYNOMIALS SUGGESTED BY THE LAGUERRE POLYNOMIALS
}

\author{
H. M. SRIVAstava
}

Recently, Joseph D. E. Konhauser discussed two polynomial sets $\left\{Y_{n}^{\alpha}(x ; k)\right\}$ and $\left\{Z_{n}^{\alpha}(x ; k)\right\}$, which are biorthogonal with respect to the weight function $x^{\alpha} e^{-x}$ over the interval $(0, \infty)$, where $\alpha>-1$ and $k$ is a positive integer. For the polynomials $Y_{n}^{\alpha}(x ; k)$, the following bilateral generating function is derived in this paper:

$$
\begin{gathered}
\sum_{n=0}^{\infty} Y_{n}^{\alpha}(x ; k) \zeta_{n}(y) t^{n}=(1-t)^{-(\alpha+1) / k} \exp \left\{x\left[1-(1-t)^{-1 / k}\right]\right\} \\
\cdot G\left[x(1-t)^{-1 / k}, \quad y t /(1-t)\right],
\end{gathered}
$$

where

$$
G[x, t]=\sum_{n=0}^{\infty} \lambda_{n} Y_{n}^{\alpha}(x ; k) t^{n},
$$

the $\lambda_{n} \neq 0$ are arbitrary constants, and $\zeta_{n}(y)$ is a polynomial of degree $n$ in $y$ given by

$$
\zeta_{n}(y)=\sum_{r=0}^{n}\left(\begin{array}{l}
n \\
r
\end{array}\right) \lambda_{r} y^{r}
$$

It is also shown that the polynomials $Z_{n}^{\alpha}(x ; k)$ can be expressed as a finite sum of $Z_{n}^{\alpha}(y ; k)$ in the form

(4) $\quad Z_{n}^{\alpha}(x ; k)=\left(\frac{x}{y}\right)^{k n} \sum_{r=0}^{n}\left(\begin{array}{c}\alpha+k n \\ k r\end{array}\right) \frac{(k r) !}{r !}\left[(y / x)^{k}-1\right]^{r} Z_{n-r}^{\alpha}(y ; k)$.

For $k=2$, formulas (1) and (4) yield corresponding properties for the polynomials introduced earlier by Preiser [4]. Moreover, when $k=1$, both (1) and (4) would reduce to similar results involving the generalized Laguerre polynomials $L_{n}^{\alpha}(x)$. For results analogous to (1) and (4), involving certain classes of functions, the reader may be referred to our papers [5] and [6], respectively.

2. The following results will be required in our analysis.

(i) The generating function [3, p. 803]:

$$
\begin{aligned}
& \sum_{n=0}^{\infty}\left(\begin{array}{c}
m+n \\
n
\end{array}\right) Y_{m+n}^{\alpha}(x ; k) t^{n} \\
= & (1-t)^{-(\alpha+m k+1) / k} \exp \left\{x\left[1-(1-t)^{-1 / k}\right]\right\} Y_{m}^{\alpha}\left(x(1-t)^{-1 / k} ; k\right),
\end{aligned}
$$

where $m$ is any integer $\geqq 0$.

(ii) The explicit expression for $Z_{n}^{\alpha}(x ; k)$ : 
(6)

$$
Z_{n}^{\alpha}(x ; k)=\frac{\Gamma(\alpha+k n+1)}{n !} \sum_{j=0}^{n}(-1)^{j}\left(\begin{array}{c}
n \\
j
\end{array}\right) \frac{x^{k j}}{\Gamma(\alpha+k j+1)},
$$

which is equation (5), p. 304 of Konhauser [2].

From (6) it follows fairly easily that

$$
\begin{aligned}
& \sum_{n=0}^{\infty} Z_{n}^{\alpha}(x ; k) \frac{t^{n}}{(\alpha+1)_{k n}} \\
= & e_{0}^{t} F_{k}\left[-;(\alpha+1) / k, \cdots,(\alpha+k) / k ;-(x / k)^{k} t\right],
\end{aligned}
$$

since $k$ is a positive integer.

3. Proof of the bilateral generating function (1). Substituting for the coefficients $\zeta_{n}(y)$ from (3) on the left-hand side of (1), we find that

$$
\begin{aligned}
\sum_{n=0}^{\infty} Y_{n}^{\alpha}(x ; k) \zeta_{n}(y) t^{n}= & \sum_{n=0}^{\infty} Y_{n}^{\alpha}(x ; k) t^{n} \sum_{r=0}^{n}\left(\begin{array}{l}
n \\
r
\end{array}\right) \lambda_{r} y^{r} \\
= & \sum_{r=0}^{\infty} \lambda_{r}(y t)^{r} \sum_{n=0}^{\infty}\left(\begin{array}{c}
n+r \\
r
\end{array}\right) Y_{n+r}^{\alpha}(x ; k) t^{n} \\
= & (1-t)^{-(\alpha+1) / k} \exp \left\{x\left[1-(1-t)^{-1 / k}\right]\right\} \\
& \cdot \sum_{r=0}^{\infty} \lambda_{r} Y_{r}^{\alpha}\left(x(1-t)^{-1 / k} ; k\right)(y t /(1-t))^{r},
\end{aligned}
$$

by applying (5), and formula (1) would follow if we interpret this last expression by means of (2).

4. Proof of the summation formula (4). In the generating function (7), if we set $t=(y / k)^{k} z$, we shall get

$$
\sum_{n=0}^{\infty} Z_{n}^{\alpha}(x ; k) \frac{(y / k)^{k n} z^{n}}{(\alpha+1)_{k n}}=\exp \left\{(y / k)^{k} z\right\}_{0} F_{k}\left[-\left(x y / k^{2}\right)^{k} z\right],
$$

which, on interchanging $x$ and $y$, gives us

$$
\sum_{n=0}^{\infty} Z_{n}^{\alpha}(y ; k) \frac{(x / k)^{k n} z^{n}}{(\alpha+1)_{k n}}=\exp \left\{(x / k)^{k} z\right\}_{0} F_{k}\left[-\left(x y / k^{2}\right)^{k} z\right],
$$

where, for convenience,

$$
{ }_{0} F_{k}[\xi] \equiv{ }_{0} F_{k}[-;(\alpha+1) / k, \cdots,(\alpha+k) / k ; \xi] .
$$

From (8) and (9) it follows at once that

$$
\begin{aligned}
& \sum_{n=0}^{\infty} Z_{n}^{\alpha}(x ; k) \frac{(y / k)^{k n} z^{n}}{(\alpha+1)_{k n}} \\
= & \exp \left\{z\left[(y / k)^{k}-(x / k)^{k}\right]\right\} \sum_{n=0}^{\infty} Z_{n}^{\alpha}(y ; k) \frac{(x / k)^{k n} z^{n}}{(\alpha+1)_{k n}},
\end{aligned}
$$


and on equating coefficients of $z^{n}$ in (11), we shall be led to our summation formula (4).

5. Applications. First of all we notice that formula (4) may be rewritten as

$$
Z_{n}^{\alpha}(\mu x ; k)=\sum_{r=0}^{n}\left(\begin{array}{c}
\alpha+k n \\
k r
\end{array}\right) \frac{(k r) !}{r !} \mu^{k(n-r)}\left(1-\mu^{k}\right)^{r} Z_{n-r}^{\alpha}(x ; k),
$$

which provides us with a multiplication formula for the polynomials $Z_{n}^{\alpha}(x ; k)$.

On the other hand, by assigning suitable values to the arbitrary coefficients $\lambda_{n}$ it is fairly straightforward to obtain, from our formula (1), a large variety of bilateral generating functions for the polynomials $Y_{n}^{\alpha}(x ; k)$. For instance, if we let

$$
\lambda_{n}=\frac{(-1)^{n}}{\Gamma(\beta+l n+1)}, \quad n=0,1,2, \cdots ; l=1,2,3, \cdots ;
$$

and make use of the definition (6), we shall readily arrive at the bilateral generating function

$$
\begin{aligned}
& \sum_{n=0}^{\infty} \frac{n !}{\Gamma(\beta+l n+1)} Y_{n}^{\alpha}(x ; k) Z_{n}^{\beta}(y ; l) t^{n} \\
= & (1-t)^{-(\alpha+1) / k} \exp \left\{x\left[1-(1-t)^{-1 / k}\right]\right\} H\left[x(1-t)^{-1 / k},-y^{l} t /(1-t)\right],
\end{aligned}
$$

where, for convenience,

$$
H[x, t]=\sum_{n=0}^{\infty} Y_{n}^{\alpha}(x ; k) \frac{t^{n}}{\Gamma(\beta+l n+1)} .
$$

For $k=l=1$ and $\alpha=\beta$, the generating relation (14) would evidently reduce to the well-known Hille-Hardy formula for the Laguerre polynomials.

\section{REFERENCES}

1. Joseph D. E. Konhauser, Some properties of biorthogonal polynomials, J. Math. Anal. Appl., 11 (1965), 242-260.

2.—, Biorthogonal polynomials suggested by the Laguerre polynomials, Pacific J. Math., 21 (1967), 303-314.

3. T. R. Prabhakar, On the other set of the biorthogonal polynomials suggested by the Laguerre polynomials, Pacific J. Math., 37 (1971), 801-804.

4. S. Preiser, An investigation of biorthogonal polynomials derivable from ordinary differential equations of the third order, J. Math. Anal. Appl., 4 (1962), 38-64.

5. J. P. Singhal and H. M. Srivastava, $A$ class of bilateral generating functions for certain classical polynomials, Pacific J. Math., 42 (1972), 755-762. 
6. H. M. Srivastava, On q-generating functions and certain formulas of David Zeitlin, Illinois J. Math., 15 (1971), 64-72.

Received September 7, 1972 and in revised form March 8, 1973. Supported in part by NRC grant A-7353. See Abstract 72T-B97 in Notices Amer. Math. Soc., 19 (1972), p. A-437.

UNIVERSITY OF VICTORIA 


\section{PACIFIC JOURNAL OF MATHEMATICS}

\section{EDITORS}

RICHARD ARENS (Managing Editor)

University of California

Los Angeles, California 90024

\section{R. A. Beaumont}

University of Washington

Seattle, Washington 98105

\section{J. DuGundJI*}

Department of Mathematics

University of Southern California

Los Angeles, California 90007

D. Gilbarg and J. Milgram

Stanford University

Stanford, California 94305

ASSOCIATE EDITORS
E. F. BECKENBACH
B. H. NeumanN
F. WOLF
K. YoSHIDA

\section{SUPPORTING INSTITUTIONS}

UNIVERSITY OF BRITISH COLUMBIA

CALIFORNIA INSTITUTE OF TECHNOLOGY

UNIVERSITY OF CALIFORNIA

MONTANA STATE UNIVERSITY

UNIVERSITY OF NEVADA

NEW MEXICO STATE UNIVERSITY

OREGON STATE UNIVERSITY

UNIVERSITY OF OREGON

OSAKA UNIVERSITY

\author{
UNIVERSITY OF SOUTHERN CALIFORNIA \\ STANFORD UNIVERSITY \\ UNIVERSITY OF TOKYO \\ UNIVERSITY OF UTAH \\ WASHINGTON STATE UNIVERSITY \\ UNIVERSITY OF WASHINGTON \\ AMERICAN MATHEMATICAL SOCIETY \\ NAVAL WEAPONS CENTER
}

The Supporting Institutions listed above contribute to the cost of publication of this Journal, but they are not owners or publishers and have no responsibility for its content or policies.

Mathematical papers intended for publication in the Pacific Journal of Mathematics should be in typed form or offset-reproduced, (not dittoed), double spaced with large margins. Underline Greek letters in red, German in green, and script in blue. The first paragraph or two must be capable of being used separately as a synopsis of the entire paper. Items of the bibliography should not be cited there unless absolutely necessary, in which case they must be identified by author and Journal, rather than by item number. Manuscripts, in duplicate if possible, may be sent to any one of the four editors. Please classify according to the scheme of Math. Rev. Index to Vol. 39. All other communications to the editors should be addressed to the managing editor, or Elaine Barth, University of California, Los Angeles, California, 90024.

50 reprints are provided free for each article; additional copies may be obtained at cost in multiples of 50 .

The Pacific Journal of Mathematics is issued monthly as of January 1966. Regular subscription rate: $\$ 48.00$ a year (6 Vols., 12 issues). Special rate: $\$ 24.00$ a year to individual members of supporting institutions.

Subscriptions, orders for back numbers, and changes of address should be sent to Pacific Journal of Mathematics, 103 Highland Boulevard, Berkeley, California, 94708.

\section{PUBLISHED BY PACIFIC JOURNAL OF MATHEMATICS, A NON-PROFIT CORPORATION}

Printed at Kokusai Bunken Insatsusha (International Academic Printing Co., Ltd.), 270, 3-chome Totsuka-cho, Shinjuku-ku, Tokyo 160, Japan.

* C. R. DePrima California Institute of Technology, Pasadena, CA 91109, will replace J. Dugundji until August 1974.

Copyright (C) 1973 by

Pacific Journal of Mathematics

All Rights Reserved 


\section{Pacific Journal of Mathematics}

\section{Vol. 49, No. $2 \quad$ June, 1973}

Wm. R. Allaway, On finding the distribution function for an orthogonal polynomial

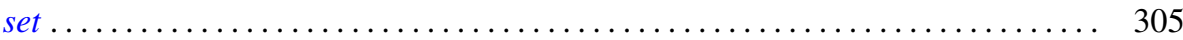

Eric Amar, Sur un théorème de Mooney relatif aux fonctions analytiques bornées... . 311

Robert Morgan Brooks, Analytic structure in the spectrum of a natural system . . . . 315

Bahattin Cengiz, On extremely regular function spaces . . . . . . . . . . . . . . 335

Kwang-nan Chow and Moses Glasner, Atoms on the Royden boundary . . . . . . . . . 339

Paul Frazier Duvall, Jr. and Jim Maxwell, Tame $Z^{2}$-actions on $E^{n} \ldots \ldots \ldots \ldots \ldots . .349$

Allen Roy Freedman, On the additivity theorem for $n$-dimensional asymptotic

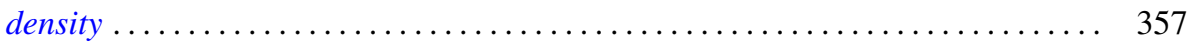

John Griffin and Kelly Denis McKennon, Multipliers and the group $L_{p}$-algebras . . . 365

Charles Lemuel Hagopian, Characterizations of $\lambda$ connected plane continua ....... 371

Jon Craig Helton, Bounds for products of interval functions . . . . . . . . . . . 377

Ikuko Kayashima, On relations between Nörlund and Riesz means . . . . . . . . . . 391

Everett Lee Lady, Slender rings and modules . . . . . . . . . . . . . . . . . . 397

Shozo Matsuura, On the Lu Qi-Keng conjecture and the Bergman representative

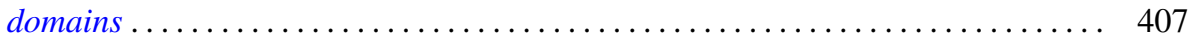

Stephen H. McCleary, The lattice-ordered group of automorphisms of an $\alpha$-set . . . 417

Stephen H. McCleary, o-2-transitive ordered permutation groups .......... 425

Stephen H. McCleary, o-primitive ordered permutation groups. II . . . . . . . . . 431

Richard Rochberg, Almost isometries of Banach spaces and moduli of planar

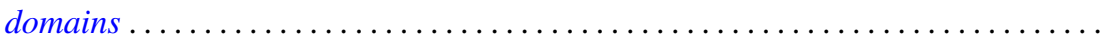

R. F. Rossa, Radical properties involving one-sided ideals . . . . . . . . . . . . . 467

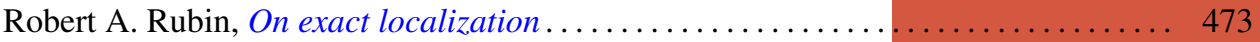

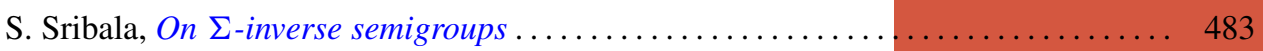

H. M. (Hari Mohan) Srivastava, On the Konhauser sets of biorthogonal polynomials suggested by the Laguerre polynomials ...................... 489

Stuart A. Steinberg, Rings of quotients of rings without nilpotent elements . ...... 493

Daniel Mullane Sunday, The self-equivalences of an $H$-space . . ............ 507

W. J. Thron and Richard Hawks Warren, On the lattice of proximities of $\check{C} e c h$

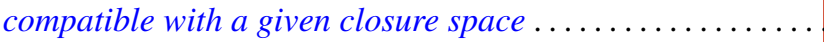

Frank Uhlig, The number of vectors jointly annihilated by two real quadratic forms determines the inertia of matrices in the associated pencil .

Frank Uhlig, On the maximal number of linearly independent real vectors annihilated simultaneously by two real quadratic forms ..............

Frank Uhlig, Definite and semidefinite matrices in a real symmetric matrix pencil . . 561

Arnold Lewis Villone, Self-adjoint extensions of symmetric differential operators . . . 569

Cary Webb, Tensor and direct products . ....................... 579

James Victor Whittaker, On normal subgroups of differentiable

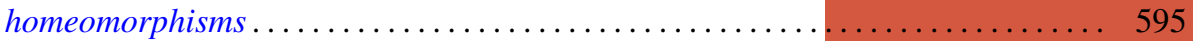

Jerome L. Paul, Addendum to: "Sequences of homeomorphisms which converge to

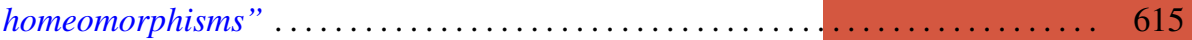

David E. Fields, Correction to: “Dimension theory in power series rings” ........ 616

Peter Michael Curran, Correction to: “Cohomology of finitely presented groups”. . . 617

Billy E. Rhoades, Correction to: “Commutants of some Hausdorff matrices” ...... 617

Charles W. Trigg, Corrections to: "Versum sequences in the binary system” ...... 619 